\title{
Personal and Bibliographical
}

\section{J. W. GARNER}

The committee on program of the fourth annual meeting of the American Political Science Association, which will be held at Madison, Wis., during the last week of December, announce that the sessions will be devoted to papers and discussions upon the following subjects: Friday evening, December 27 (joint session with the American Historical Association), Presidential Addresses; Saturday forenoon, December 28, The Relations of the United States to the Latin American Republics; Saturday afternoon, The Newer Institutional Forms of Democracy; Monday forenoon, December 30 (joint session with the National Municipal League), Police Administration in the United States; Monday afternoon, business session report of the committee on the teaching of American government in secondary schools; Section Meeting on Comparative Legislation. Subject: The Methods of Work in Legislative Reference Bureaus; Monday evening, The Administration of Punitive Justice and its Reform; Tuesday forenoon, December 31 (joint session, with the American Economic Association), The Public Utilities Acts of New York and Wisconsin: The Section on Colonies and Dependencies will meet Tuesday forenoon.

Prof. C. E. Merriam of the University of Chicago spent the summer in England and Scotland, studying British municipal conditions.

Prof. John A. Fairlie has been elected a delegate to the forthcoming constitutional convention of Michigan. Professor Fairlie expects to bring out at an early date a volume of essays on municipal government to be published by the Macmillan Company.

Dr. Robert H. Whitten, for the last seven years sociology librarian of the New York State Library, has been appointed secretary of the public utilities commission for the city of New York. Mr. Frederick D. Bramhall, of the University of Chicago, has been appointed as Dr. Whitten's successor.

Dr. C. D. Tenney has been appointed lecturer on Chinese history and institutions at Harvard University for the present year.

Dr Jesse S. Reeves, formerly a member of the Indiana bar, has been appointed assistant professor of political science in Dartmouth College. Mr. Reeves received his doctor's degree at Johns Hopkins University in 1894 and recently held the Albert Shaw lectureship in that University. $\mathrm{He}$ is the author of The International Beginnings of the Congo Free 
State and of The Napoleonic Exiles in America. Dr. Frank A. Updyke (Brown, 1905) has also been added to the Dartmouth faculty with the title of assistant professor of political science. He is the author of a monograph, entitled The Treaty of Ghent and the International Negotiations Relative to the War of 1812.

Prof. T. S. Woolsey of Yale University is spending his sabbatical year abroad. His work in international law is being taken by Prof. Chas. C. Hyde of Northwestern University. Prof. Edward V. Raynolds has returned to Yale from his sabbatical year abroad and has resumed his classes in comparative law.

New additions to the faculty of the University of Pennsylvania are Murray W. Gross, assistant in political sicence, and Henry R. Mussey, assistant professor of sociology.

Mr. Gromer, instructor in history in the University of Missouri, has been appointed treasurer of Porto Rico to succeed Mr. W. F. Willoughby, who has been promoted to the secretaryship of the island.

Prof. F. J. Goodnow of Columbia University is spending his sabbatical year in a tour around the world. His work is being given during his absence by Dr. Thomas Reed Powell.

Dr. Chas. A. Beard has been appointed adjunct professor of political science at Columbia on the Blumenthal foundation. His graduate work was done at Oxford and Columbia. He is the author of The Office of Justice of the Peace in England and An Introduction to the English Historians.

The Carpentier lectures on The Science of Law at Columbia University for 1907-1908 will be given by Prof. John C. Gray of Harvard University.

Prof. J. W. Jenks will deliver a course of lectures at Columbia University this fall, on The Principles of Politics from the Viewpoint of an American Citizen. The lectures are given on the Blumenthal foundation.

Dr. William H. Allen, for some years past the general agent for the New York Society for Improving the Condition of the Poor, has been appointed director of the newly created bureau of municipal research in New York City. Mr. Robert Bruére has been chosen as his successor.

Dr. J. L. Barnard of Philadelphia has published a detailed study of the history and workings of factory legislation in Pennsylvania. (J. C. Winston Company, Phila.) 
The first two volumes of Alleyne Ireland's monumental series on oriental colonization have appeared from the press. These volumes deal with the administration of British Burma.

G. W. Prothero, D.Litt., LL.H., editor of the Quarterly Review and sometime professor of history in the University of Edinburgh, has accepted the invitation of Harvard College to deliver a course of lectures on The Constitutional History of England from the Great Charter to the Fifteenth Century during the second half of the current academic year.

The National Municipal League has announced that the William $\mathrm{H}$. Baldwin Prize for the coming year will be awarded for the best essay written by an undergraduate student in an American college or university on The Relation of the Municipality to the Street Railway Service. Further information may be had from Prof. L. S. Rowe, chairman of the League's committee on the administration of the prize.

A second examination of candidates for the consular service was recently held at Washington. Of the fifty-four candidates who were designated, thirty-eight presented themselves for examination and thirteen passed.

Governor Guild of Massachusetts, under authority of a resolution of the General Court, has appointed a commission of five persons to investigate the subject of old age insurance and pensions, with a view to establishing such a system in that State.

At a recent meeting of prominent citizens held in Albany, N. Y., plans were adopted for the formation of a State legislative league to obtain publicity in regard to all proposed measures before the State legislature.

The election of delegates to the forthcoming constitutional convention in Michigan was held on September 17. There are ninety-six members altogether, a majority of whom are lawyers, including some of the leading members of the profession. The most important questions to come before the convention relate to restrictions upon special legislation, home rule for cities, taxation, and the initiative and referendum. The convention meets October 22 , and will probably be in session until the latter part of January. The new constitution will be submitted to the voters in April.

The next meeting of the National Municipal League will be held at Providence, November 19-22, in conjunction with the American Civic Association. In addition to the annual address of President Bonaparte, 
the review of municipal progress by Secretary Woodruff and the reports of the various committees. there will be about fifteen addresses on different phases of municipal and State taxation by specialists in this field; among whom may be mentioned Profs. Seligman, Plehn, Merriam and Wilcox, Frederic C. Howe, Hon. F. N. Judson, Chas. E. Sprague, Geo. F. Seward and H. T. Newcomb. An address on National Parties in Local Elections will be delivered by Mayor Brand Whitlock of Toledo, and a discussion of electoral reform will be participated in by a number of speakers, including Thos. Raeburn White, Robt. Treat Paine, Wm. M. Ivins, Philip Loring Allen, Walter L. Fisher, J. Hampton Moore and others. The commission plan of government will be discussed by Prof. W. B. Munro, S. B. Allen, Admiral Chadwick and others. On Thursday evening there will be a dinner at which addresses will be delivered by Presidents Bonaparte and McFarland, Governors Guild and Higgins, President Faunce and Secretary Woodruff. On Thursday and Friday mornings there will be joint sessions of both associations at which addresses will be made by a number of distinguished speakers.

Henry Holt and Company have conferred a service upon students of early social and political institutions by reprinting, in comparatively inexpensive form, Lewis H. Morgan's Ancient Society. The original edition of 1877 is followed without change or addition.

A New York State library bulletin, entitled Legislative Reference Lists, 1906, contains brief bibliographies on life insurance, direct nominations, and the inheritance tax.

A select list of books on the French alliance with the United States, prepared by Mr. A. P. C. Griffin, has recently been published by the Library of Congress.

Mr. Courtney S. Kenny's Outlines of the Criminal Law has been revised and adapted for American scholars by James H. Webb (Macmillan). For the general reader and layman it possesses particular merits and to this class the new edition is mainly addressed.

The International Bureau of the American Republics at Washington, D. C., has issued two valuable volumes entitled American Constitutions: A Compilation of the Political Constitutions of the Independent Nations of the New World. These constitutions are given in both the original texts and English translations. In volume one are given the instruments of government of the federal unions, and of the republies of Central America. Volume two contains the constitutions of the republics of the Caribbean Sea, and of South America. A third volume is promised 
which, besides the general index, will contain the articles of confederation and perpetual union, the Constitution of the great Colombiaa confederation which by its dissolution gave rise to the republics of Venezuela, New Granada and Ecuador-the Constitution of the United Provinces of Central America (Las Provincias unidas de Centro América), a confederation which was created in 1824, and other documents illustrating the development of political life in the nations of the New World. The editor is José Ignacio Rodiquez, chief translator and librarian of the Bureau.

The American Economic Association will soon begin the publication of a periodical which will be devoted almost entirely to reviews of books and other publications upon economic and sociological topics. These reviews will include summaries of important magazine articles on subjects of an economic or sociological character, whether they appear in periodicals devoted mainly to such subjects or in periodicals only occasionally and incidentally treating them. This new periodical will be known as the Economic Bulletin, and will appear quarterly. It will contain from 80 to 100 pages and will be the first American attempt to provide a complete current critical bibliography of economics. The managing editor will be Prof. C. W. A. Veditz of the George Washington University.

The International Labor Office has begun the publication of an English edition of its Bulletin, which it has published in French and German editions since 1902. This Bulletin gives a complete survey of the progress of labor and social legislation in all countries of the world. The Bulletin contains either the full text or adequate summaries, not only of laws, but also of administrative orders concerning the regulation of hours of work, conditions of labor, accidents, insurance, and other matters affecting the working classes. It traces the progress of labor legislation by giving an account of the preliminary enquiries and debates in legislative bodies, the resolutions of public meetings, and a general review of the progress of opinion in different countries. It also supplies a bibliography of labor legislation and labor statistics. The 1907 volume - the first of the English edition-includes in the year's review, the texts of the trade disputes act and the workmen's compensation act, and an account of legislative and administrative action in different countries in relation to unemployment. It further contains a review of the labor laws of the United States as they were in the year 1904, and a translation of all the notes on international labor treaties which have 
appeared in back numbers of the French and German editions. The Bulletin is published by the Newspaper Printing and Publishing Company, Ltd., Woolwich, England. The annual subscription is eight shillings.

Messrs G. P. Putnam's Sons announce Law: Its Origin, Growth and Function, by the late James C. Carter of the New York bar. The volume is to consist of a series of lectures prepared for delivery before the Iaw school of Harvard University but never delivered, owing to the death of the author. The lectures do not constitute a technical treatise upon any branch of the law but rather a comprehensive study of its origin and development as a science and its influence and function in the civilization of mankind.

The Prisoner at the Bar (Scribners) by Arthur Train, an assistant prosecuting attorney in New York City, is the title of a book which throws much light on the actual administration of the criminal law. In a series of entertaining chapters, most of which are enlivened with amusing anecdotes, he portrays the workings of the courts as he has seen them in New York City. Some of the subjects with which he deals are the judge, the jury, the witness, the verdict, the law's delays, and the "tricks of the trade." Mr. Train's observations go to show what is now generally admitted on all hands that our judicial procedure is in many respects archaic and that the American people as a whole lack respect for law.

The Boston Book Company announces the early publication of a collection of essays on constitutional law by the late James B. Thayer; also a new work on constitutional law by Mr. F. J. Stimson. The latter is to be a comparative study of the Constitutions of the United States and of the individual States thus forming a treatise on American constitutional law as a whole.

Mr. Soule, president of the Boston Book Company, who has for a number of years made annual trips to England for the purpose of purchasing books on the common law for his house, this year, on account of the increasing interest in foreign law, extended his trip to the continent for the purpose of adding to his stock a collection of continental codes, treatises and miscellaneous works on the civil law.

Among recent publications in the Columbia University Studies are The Finances of Cleveland, by Chas. C. Williamson, Ph.D.; Trade and Currency in Early Oregon, by Jas. H. Gilbert, Ph.D.; The Tobacco Industry in the United States by Meyer Jacobstein, Ph.D.; Social Democracy 
and Population by Alvan A. Tenny, Ph.D.; The United States Steel Corporation by Abraham Berglund, Ph.D.; The Taxation of Corporations in Massachusetts by Harry G. Friedman, A.B.; and De Witt Clinton and the Origin of the Spoils System in New York, by Howard Lee McBain, Ph.D.

The State in Constitutional and International Law, by Robert Treat Crane, is the title of a recent number of the Johns Hopkins University Studies. Dr. Crane attempts to reconcile the apparently conflicting theories of divisible and indivisible sovereignty by distinguishing between the State as a concept of constitutional law and the State as a concept of international law and by restricting the applicability of the two theories to separate and distinct spheres. The study is marked by originality of thought and discriminating judgment.

Among the new publications of Longmans, Green and Company is a History of Commerce, by Prof. Clive Day of Yale University, and an Economic History of the United States, by Prof. Ernest L. Bogart of Princeton University. Professor Day's work is divided into five parts dealing successively with the history of commerce in ancient, medieval, modern, and recent times and with the commerce of the United States. Professor Bogart's history traces the growth of agriculture, commerce, transportation and labor from their colonial beginnings to the complex industrial and commercial society of today. Suggestive topics and bibliographies accompany each chapter and there is a general bibliography at the end of the volume.

Prof. Cephas D. Allin, of Queen's College, Ontario, is the author of a new work entitled The Early Federation Movement in A ustralia (British Whig Publishing Company, Kingston, Ontario, 1907), being a review of the federal movement among the Australian States during the first twenty years of its history. Mr. Allin confines his study mainly to the parliamentary aspects of the struggle rather than to the history of the movement as a popular contest. The early movement was embodied in the policy of Lord Grey, secretary of state for the colonies, and in the activities of a few leading members of the Australian legislatures. It is this stage of the movement which constitutes the subject of $\mathrm{Mr}$. Allin's treatise and to which he devotes more than four hundred pages.

A study in Belgian criminology which has attracted considerable attention is La Belgique criminelle (Lecoffre, Paris), by Henri Joly, a member of the French Institute. The study was undertaken under the auspices of the academy of moral and political sciences of Paris and embodies the results of extensive investigation of the criminal records 
of Belgium. The author finds that Belgium like most other countries has been afflicted with an increase of crime which he attributes mainly to the increased sonsumption of intoxicating liquors.

A valuable work which appeared almost contemporaneously with the assembling of the second Hague conference is Herr von Otfried Nippold's Die Fortbildung des Verfahrens in völkerrechtlichen Streitigkeiten (Duncker and Humblot, Leipzig) an elaborate study of the nature and development of arbitral procedure in the settlement of international controversies.

Prof. Paul Laband's Deutsches Staatsrecht has been reissued as the initial volume of Jellinek, Laband and Piloty's proposed monumental work entitled Das offentliche Recht der Gegenwart which has been planned along the lines of Marquardsen's well known Handbuch and which, it is announced, will be completed within about six years. J. C. B. Mohr of Tübingen is the publisher.

A new and revised edition of Sir Courtenay Ilbert's The Government of India (Clarendon Press) first published in 1898 has recently appeared. In addition to the digest of the laws relating to the government of India there is an historical introduction and a discussion of the applicability of English law to the native States and of the legal relation of the British government to the government of the native States. The new edition was made necessary by the changes introduced into the government of India by the recent orders in council relative to the jurisdiction of the governor-general over the native States.

A new English translation of Prince Kropotkin's Conquest of Bread (Putnam's) contains a good exposition of his principles of anarchy.

Prof. William G. Sumner of Yale University has written a stout volume of nearly 700 pages on the subject of Folkways (Ginn, 1907), which he describes as a study of the sociological importance of usages, manners, customs, and morals. In the first two chapters he attempts to show that the folkways are habits of the individual and customs of the society which arise from efforts to satisfy needs. In succeeding chapters he deals with the struggle for existence, labor, wealth, societal selection, slavery, cannibalism, sex morals, the marriage institution, the social codes, kinship, educational history, and various other subjects. The work bears evidence of wide reading and extended research.

Licensing and Temperance in Sweden, Norway and Denmark, by Edwin A. Pratt (Dutton), is mainly an exposition of the Gothenburg and Copenhagen systems of controlling the liquor traffic. The book also gives a 
somewhat detailed account of the actual working out of the systems in their respective countries based upon extended personal observation of the author. He condemns rather severely the Gothenburg method but thinks the Copenhagen system worthy of serious consideration.

The Lodging House Problem in Boston, by Albert Benedict Wolfe, $\mathrm{Ph} . \mathrm{D}$. (Houghton, Mifflin and Company), is the title of one of the recent issues of the Harvard Historical Series.

A new edition of Reinhard Frank's Commentary on the German Imperial Criminal Code, including the introductory law (Einführungsgesetz), is announced by J. C. B. Mohr.

The July number of the Archiv für Sozial Wissenschaft and Sozial Politik contains the first instalment of what promises to be a valuable study of the Austro-Hungarian Ausgleich by Friedrich Gaertner. The same number contains an interesting article on the German social democracy in international alliances by Robt. Michels.

The last number of the Zeitschrift für die gesammte Staatswissenschaft contains an elaborate contribution on the subject of parliamentary freedom of speech and protection against its abuses, by Dr. F. W. R. Zimmerman.

The first volume of a work, entitled Le droit constitutionnel de la Belgique, Бy O. Orbran, has recently been published by Giard et Brière.

Students of the American law of citizenship will be interested in an article published in the August number of the Revue de droit international et de législation comparée by Ernest Lehr, entitled Nationalité et de la naturalization d'après la législation actuelle des Etats d' Amérique. M. Lehr comments on the new citizenship law and explains the changes which it has introduced into American practice.

It is announced that the German colonial office has launched a project for the establishment of regular prescribed courses of instruction on the German colonies in the public schools with a view to arousing a more general popular interest in Germany's colonial possessions.

The French government has arranged for the publication of the documents relating to the diplomatic history of the Franco-German War of 1870-71. The committee on publication, consists of MM. Aulard, Bourgeois, Reinach, Farges and Mandel.

A project of a model code of international public law in 786 articles to be adopted by a proposed international conference representing all nations 
and embodied in a convention to be accepted by all States participating in the conference has been outlined by E. Duplessis in a work entitled La loi des nations, projet d'institution d'une autorité internationale législative, administrative et judiciaire, et d'un code de droit international public (Paris, librairie Laroze). The work has been crowned with a prize given by the International Peace Bureau.

Le monde et la guerre russo japonaise, by André Chéradame (Plon Nourrit et Cie, Paris), is the title of another contribution to the literature of the Russo-Japanese war. The work is divided into two parts: Part I is mainly a history of the war based largely on personal observation; Part II deals with the results of the war on the political and economic situation in Asia, Europe and the United States.

Dr. Heinrich Sievering of the University of Marburg has been called to the University of Zürich as professor of political science to succeed Prof. Herkner.

Dr. Otto Lenel, professor of Roman and German law in the University of Strasburg, has been called to a similar chair in the University of Freiburg. Professor Lenel's chair at Strasburg has been filled by the appointment of Dr. Otto Gradenwitz, professer of Roman and German civil law in the University of Königsberg.

Dr. Rudolph Leonhard, professor of Roman law, civil procedure and Prussian constitutional law in the University of Breslau, has been appointed Kaiser Wilhelm professor of law and political science in Columbia University for the year 1907-1908. Professor Leonhard delivered his inaugural lecture at Columbia on September 27, his subject being The Historical Development of Law.

Dr. Gustav Rümelin, professor of Roman and civil law in the University of Freiburg died June 12, at the age of fifty-nine years. He was the author of various works on political and legal subjects one of which was several years ago translated into English under the title Politics and the Moral Law.

Dr. Conrad Bornhak, professor of constitutional law and Prussian administrative law in the University of Berlin, has recently added another volume to his already long list of standard works. The new volume is entitled Grundriss des deutschen Staatsrechts (Böhne, Leipzig, 1907), and treats (1) of the constitutional law of the individual States, (2) of imperial constitutional law, and (3) of constitutional law in general. 
Yves Guyot, the well known French scholar and publicist, is the author of a new work entiled La démocratie individualiste (Paris, Giard et Brière). He maintains that the trend of human development is in the direction of individualism rather than toward socialism and defends his position with both courage and ability. His new work is a brilliant presentation of the individualistic doctrines though it is not without evidence of partisanship.

The conditions in Morocco which led to the recent intervention, the calling of the conference at Algeciras, the proceedings and acts of the conference and, in general, the diplomatic history of the Moroccan "crisis," have been made the subject of a work by André Tardieu entitled La conférence d'Algésiras (Félix Alcan, Paris).

A new, enlarged and revised edition of M. Andreani's La condition des étrangers en France et la législation sur la nationalité has recently appeared from the house of Alcan (Paris).

M. Réné Worms, the editor of the Revue internationale de sociologie, and one of the most prolific and erudite of living writers on sociological questions, has lately published the third volume of his studies on the philosophy of the social sciences, under the title Conclusions des sciences sociales. The two preceding volumes deal with the objects and methods of the social sciences (Giard et Brière, Paris).

The international status of railroads in belligerent territory, including the rights and obligations of belligerents in relation to railways in time of war, is the subject of a study entitled Die Eisenbahnen im Kriege, by Karl Nowacki, a Polish engineer and doctor of law (Frank, Zürich).

The first volume of a treatise on private international law has lately been published by P. D. Sakellarios of Athens. The author is Georges Streit, a professor in the University of Athens, a meinber of the Hague permanent court of arbitration and a scholar with a European reputation.

Another study in private international law is a monograph entitled De la nationalité en Roumanie by André J. Suciu, a member of the law faculty of the University of Paris. It is the initial volume in a series of similar studies which are expected to form a history of the law and juridical institutions of Roumania (Bonvalot-Jouve, Paris).

The second part of Professor Mérignhac's Traité de droit public international, consisting of a volume of over eight hundred pages has lately appeared as one of the volumes in the Librairie général de droit 
et de jurisprudence (Paris). The first part, dealing with general theories, appeared in 1905. The present volume is devoted to the law of peace and is to be followed by several additional volumes.

The services of Lord Milner to the British empire from 1897 to 1902 and his political career in South Africa form the subject of a somewhat laudatory work by W. Basil Worsford, entitled Lord Milner's Work in South Africa (Dutton).

A work which should prove of interest to students of colonial government is MM. Chas. de Lannoy and Herman Van der Linden's Histoire de l'expansion colonial des peuples européens (Paris, Alcan). The present volume is devoted to Spain and Portugal to the end of the nineteenth century and deals not only with the history of colonial expansion but with colonial enterprises, methods of administration, the economic régimé and the resulting effects, political and economic, upon the mother country. Various other volumes devoted to particular countries will be added to the series and when completed it will form an elaborate history of European colonial expansion from ancient times to the present day. Each volume is to be accompanied by a valuable bibliography.

Les questions actuelles de politiques étrangères en Europe (Paris, Alcan), is the title of a collection of addresses dealing with live questions of foreign politics in Europe, delivered at the Sorbonne, during the past year under the auspices of the Ecole des sciences politiques. Great Britain, France, Germany, Russia, and the Balkan States are each handled by a specialist. There is an introduction by M. Ribot and a general discussion of the problems of foreign politics which confront Europe today, by M. Anatole Leroy-Beaulieu, director of the school.

A new and timely contribution to the literature of international law and diplomacy is La nouvelle convention de Genèva du 6 juillet, 1906 (Paris, Pedone, 1907), by Joseph Delpech, the well known jurisconsult and professor of public law in the University of Aix-Marseille. The work is not only a commentary on the new Geneva convention but is a study of the evolution of international usage and legislation for the amelioration of the sick and wounded in war, and is completed by an analysis of the necessary restrictions which the nature of war imposes upon the Red Cross Service.

M. Emile Stocquart, a Belgian advocate, has undertaken the task of writing a comprehensive treatise on the evolution of marriage considered from the juristic point of view. Two volumes have already 
appeared. The first deals with marriage in France; the second, which has just appeared, is devoted to the law of marriage in Spain. The title of the work is Aperçu de l'evolution juridique du mariage.

A new treatise on the history and development of the Constitution of Württemberg has been written by Karl Gösz under the title Die Verfassungsurkunde für das Königreich Württemberg ( J. C. B. Mohr, Tübingen).

The first volume (1906) of the Zeitschrift für Völkerrecht und Bundesstaatsrecht (Kern's Verlag, Breslau), edited by Josef Kohler with the collaboration of a group of distinguished scholars representing various countries has set a high standard. It is a volume of 638 pages filled with signed articles by eminent scholars and publicists like Le Fur, Meili, Oppenheim, Huber, Mueller, Adler and others; with texts of judicial decisions, treaties, documents, etc.; miscellaneous news; literary and bibliographical notes; book reviews; chronicles of events of a national and international character, etc.

Das parlamentarische Interpellationsrecht, by Dr. Hans Ludwig Rosegger, is the title of the latest number of the Staats- und völkerrechtliche Abhandlungen, edited by Professors Jellinek and Anschütz of Heidelberg (Duncker and Humblot, Leipzig). For purposes of treatment the study is divided into two parts. Part one is an exposition of the nature and purpose of the interpellation, its legal character, the forms which it assumes, the subjects to which it applies and the kindred forms of procedure to which it may be likened. Part two is devoted to a review of the history and actual workings of the interpellation in the imperial and Prussian parliaments, in the Austrian and Hungarian chambers, in the French Chambers of Deputies and in the English House of Commons. The monograph is one of the best in this well known series, being the first systematic study of the kind dealing with a parliamentary practice which has gained rapidly in the last few years, but which has been largely neglected by political writers.

The eighth volume of Pradier-Fodérés monumental work, entitled Traité de droit international public européen et americain, has appeared from the press (Pedone, Paris). The untimely death of M. PradierFodéré in June, 1904, prevented the completion of his great task, but happily the present volume was sufficiently advanced for publication at the time of the author's death. It is devoted to the relations of States in time of war, especially maritime war.

Recent doctors' dissertations of interest to students of political science are: Der Wohnsitz in bürgerlichen Recht, by M. Bergheim, 
Rostock; Gesetzzustimmung und Bewilligung in Königreiche sachsen, by M. Forwerg, Leipzig; Die Finanzpolitik der preussischen Gross-städte, by W. Klose, Halle; Das Oberaufsichtsrecht des Staates in modernen deutschen Staatsrecht, by W. Schoenborn, Heidelberg; Rechtsempire und Rechtstheorie, by W. Habrucker, Halle: Der Staatsangehörigkeit der juristischen Personen, by E. Isay, Bonn; Die Verantwortlichkeit des Reichskanzlers by H. Schuster, Erlangen; Das Erfordernis der ministeriellen Gegenziechnung nach dem Staatsrecht preussens und die deutschen Reichs, by W. von Loen, Breslau; Die Gegenzeichnung und die Verantwortlichkeit des Reichskanzlers auf rechts vergleichender Grundlage, by $\mathrm{H}$. Reichard, Frankfort; and Die Stellvertretung des Reichskanzlers, by K. Reumpelt, Breslau.

A new, revised and enlarged edition of Mischler and Ulbrich's Oesterreichisches Staatswörterbuch has recently appeared from the press of Hölder (Wien, 1907).

Prof. Frederic de Martens is the author of a brochure, entitled Par la justice vers la paix (Lavauzelle, Paris), being mainly a commentary on the decision of the Hague permanent court of arbitration relative to the right of Great Britain, Germany, and Italy to preferential treatment in the settlement of claims against Venezuela in 1904. Professor Martens was a member of the tribunal which rendered the award and is therefore well qualified to interpret its decision. His brochure also contains an exposition of the so-called Drago doctrine.

Les sentences arbitrales en droit international privé, by Louis Weill, a French advocate and doctor of law (Larose and Tenin, Paris) is a three hundred page treatise on the nature of arbitral awards, the enforcement of arbitration conventions, the difficulties in the way of the arbitral method of settling controversies of an international character and similar questions. The value of the work is increased by a full bibliography. A still more elaborate work on the same subject was published by M. Lainé in 1899 .

De la déclaration de guerre, by M. Maurel, with an introduction by Professor Mérignhac of the University of Toulouse (Librairie générale de droit et de jurisprudence, Paris), is a work which was crowned by a gold medal given by the law faculty of the University of Toulouse. The author discusses at length the question of the necessity of a declaration before beginning hostilities, the forms of declaration and the effects. He concludes that the declaration cannot justly be dispensed 
with and maintains that it should announce clearly and unequivocally the intention to have recourse to armed force. He, of course, reprøaches the Japanese for their conduct at Port Arthur.

A traveling fellowship carrying a stipend of 4000 marks has been awarded by the University of Berlin to Edward Heymann, a German referendar. The appointee is required to take up the study of the administration of the criminal law in foreign states and make a report thereon. The fund was provided by the later Professor Berner whose recent death was recorded in a recent number of this REview and who in his later life took a deep interest in the movement for the reform of German criminal law.

Two recent monographs dealing with the procedure of amending the constitution, particularly of the German Empire, are Dr. Georg Jellinek's Verfassungsänderung und Verfassungswandlung (Haring, Berlin), and Wilhelm Weise's Verfassungsänderungen nach Reichsrecht (Marcus, Breslau). Both authors distinguish between conscious alteration of the formal text through deliberate legal methods or revolution and changes which modify the meaning of the constitution without altering formally the text. Jellinek maintains that changes of the latter character may come from interpretation by the parliament, by the administration and by the courts as well as through political necessity and non-exercise of constitutional powers. Weise seems to admit the possibility of change through the operation of custom (Gewohnheitsrecht).

A new German publication of especial interest to students of political science has been announced to issue its first number in October, the Archiv für Rechts- und Wirthschaftsphilosophie. It is to be edited by Prof. Josef Kohler of the University of Berlin, with the assistance of Dr. Fritz Berolzheimer of Munich. 